\title{
Joanna Dynowska
}

Uniwersytet Warmińsko-Mazurski w Olsztynie

e-mail: joannan@uwm.edu.pl

\section{BUDŻET ZADANIOWY W GMINACH WOJEWÓDZTWA WARMIŃSKO-MAZURSKIEGO PERFORMANCE BUDGET IN THE MUNICIPALITIES OF WARMIA AND MAZURY VOIVODESHIP}

DOI: $10.15611 /$ pn.2017.471.11

JEL Classification: M410

Streszczenie: Celem artykułu jest diagnoza stanu wdrożeń budżetu zadaniowego w gminach województwa warmińsko-mazurskiego oraz ocena stopnia przygotowania gmin do opracowania budżetu w układzie zadaniowym. Artykuł ma również na celu identyfikację pozytywnych i negatywnych efektów wdrożenia budżetu zadaniowego. Badania przeprowadzone wśród 45 gmin województwa warmińsko-mazurskiego wykazały, że jedynie w 4 gminach wdrożono budżet zadaniowy. Ponad połowa badanych jednostek nie podjęła żadnych kroków w kierunku wdrażania budżetu w układzie zadaniowym. Pozostałe gminy tworzą bazy mierników, dokonują podziału zadania na podzadania, opisują zadania $\mathrm{z}$ uwzględnieniem finansowania oraz szkolą swoich pracowników. Największą obawę przed wdrożeniem budżetu budzi pracochłonność i długotrwałość procesu tworzenia budżetu oraz ustalenie kosztów poszczególnych zadań i szczegółowy opis tych zadań.

Słowa kluczowe: budżet zadaniowy, gminy, stan wdrożeń, efekty wdrożenia.

Summary: The aim of the paper was the diagnosis of the state of implementation of performance budget in the municipalities of Warmia and Mazury Voivodship and the evaluation of the municipalities' preparation to implement the budget in the task arrangement. The article also aimed at the identification of the difficulties and expectations referring to the implementation of performance budget. Studies conducted among 45 municipalities of Warmia and Mazury Voivodeship showed that only 4 of them had implemented the performance budget. Among the samples studied, more than a half of entities did not take any action to implement the performance budget. The rest of the municipalities created measure databases, tried to divide tasks into subtasks, described the tasks taking finances into consideration and trained their employees. The biggest anxiety in implementing the budget comprises labour-absorbency and long-running of the process of budget creating and calculating the costs of tasks as well as a detailed description of individual tasks.

Keywords: performance budget, municipalities, state of implementation, effects of implementation. 


\section{Wstęp}

Budżet w układzie zadaniowym jest jednym z elementów reformy sektora publicznego w Polsce, której celem jest poprawa jakości usług świadczonych przez jednostki. Finanse publiczne, zarówno na szczeblu centralnym, jak i szczeblu samorządów terytorialnych, potrzebują znacznych zmian, które doprowadzą do wzrostu efektywności w zarządzaniu środkami finansowymi. Narzędziem, które ma umożliwić taki wzrost, jest budżet zadaniowy. W zamyśle budżet w układzie zadaniowym koncentruje się głównie na części wydatkowej, czyli tej, która dostarcza informacji o efektywności wykorzystywanych środków publicznych. Podział na części, zadania, podzadania i działania pozwala uzyskać plan finansowy, który jest przejrzysty, zrozumiały i czytelny zarówno dla kadry zarządzającej, pracowników jednostek samorządowych, jak i mieszkańców gmin.

Nowoczesny układ budżetu nie tylko pozwala na powiązanie każdego wydatku z wcześniej określonymi celami i zadaniami, ale także umożliwia powiązanie nakładów na określone zadania z efektami, które zostały uzyskane. Dzięki temu lepiej zostają zaspokojone wszelkie potrzeby jednostek samorządowych.

Budżetowanie zadaniowe to element tworzący nowoczesne zarządzanie finansami publicznymi. Wdrożenie budżetu zadaniowego pozwala wykonywać zadania publiczne w sposób charakteryzujący się lepszym stosunkiem kosztów ich wykonania do wartości otrzymanych rezultatów. Właściwe dostosowanie zadań publicznych do aktualnych potrzeb powoduje mniejsze obciążenia finansowe na działania mniej potrzebne. Budżet zadaniowy przyczynia się także do obniżeniu kosztów wykonywanych zadań publicznych.

Doświadczenia polskich jednostek samorządu terytorialnego we wdrażaniu budżetu zadaniowego są przedmiotem analiz od prawie 20 lat [Filas i in. 1999; Pakoński 2000; Owsiak (red.) 2002; Dylewski 2007; Lubińska (red.) 2011; Malinowska-Misiąg $\mathrm{i}$ in. 2015]. W badaniach ankietowych przeprowadzonych przez Ministerstwo Finansów w 2013 r. stosowanie budżetowania zadaniowego zadeklarowało 2,8\% JST. Z kolei badania przeprowadzone przez Ministerstwo Administracji i Cyfryzacji wskazały, że średnio $17 \%$ badanych gmin deklaruje przygotowywanie budżetu zadaniowego. Na podstawie tych danych trudno jednoznacznie stwierdzić, jaka jest rzeczywista skala stosowania budżetowania zadaniowego $\mathrm{w}$ gminach. $\mathrm{O}$ istnieniu rozbieżności świadczyć mogą dodatkowo badania przeprowadzone przez Biuro Analiz Sejmowych [BAS 2013, s. 164], które wskazują, że budżet zadaniowy wprowadziło prawie 18,5\% ogółu miast na prawach powiatu [Franek 2015, 118].

Celem artykułu jest diagnoza stanu wdrożeń budżetu zadaniowego $\mathrm{w}$ gminach województwa warmińsko-mazurskiego oraz ocena stopnia przygotowania gmin do opracowania budżetu w układzie zadaniowym. Artykuł ma również na celu identyfikację pozytywnych i negatywnych efektów wdrożenia budżetu zadaniowego.

Badania przeprowadzono z wykorzystaniem metody ankietowej. Do opracowania wyników badań wykorzystano metodę analizy statystycznej, która miała na celu statystyczny opis badanej zbiorowości. 


\section{Budżet zadaniowy w gminach}

Obecnie dużą uwagę poświęca się efektywnemu wykorzystywaniu środków finansów publicznych. Taka sytuacja zmusza jednostki samorządu terytorialnego do stosowania odpowiednich narzędzi zarządzania, które będą wspomagać również rozwój gmin. Jednym z takich kluczowych narzędzi nowoczesnego zarządzania w gminach jest budżet zadaniowy.

Koncepcja budżetu zadaniowego wywodzi się z modelu New Public Management, propagującego rynkowe podejście w sektorze publicznym. Początki wprowadzania budżetu zadaniowego w Polsce sięgają roku 1994, kiedy w Krakowie rozpoczęto reformę metody planowania wydatków [Owsiak (red.) 2002]. Kolejnymi dużymi miastami, które rozpoczęły prace nad budżetem zadaniowym, były m.in. Szczecin, Warszawa, Poznań.

W roku 2009 wdrażaniem budżetu zadaniowego objęto 6 powiatów i 11 gmin województwa zachodniopomorskiego w ramach Priorytetu V (Dobre Rządzenie) Programu Operacyjnego Kapitał Ludzki [www1]. Obecnie wiele firm konsultingowych oferuje wdrażanie budżetu zadaniowego oraz szkolenia z zadaniowego planowania budżetu.

Chociaż część samorządów zaczęła wdrażać budżet zadaniowy już w latach 90., to dla większości gmin, szczególnie wiejskich, stanowi on nowość. Budżet zadaniowy wymaga przygotowania wielu dokumentów. Dodatkowo każde zadanie musi być szczegółowo opisane. W gminach brakuje specjalistów, którzy mogliby się zająć opracowaniem budżetu w nowej formie, i środków finansowych na ich zatrudnienie, szczególnie w sytuacji, kiedy gminy wykazują wydatki wyższe niż dochody.

Stosowany w jednostkach samorządu terytorialnego budżet zadaniowy, oparty na doświadczeniach amerykańskich, rozumiany jest jako „plan finansowy określający szczegółowe rzeczowo-finansowe plany zamierzeń, jakie mają realizować dysponenci, przygotowany przez administrację" [Chojna-Duch 2006, s. 254]. Zasadnicza różnica między budżetem zadaniowym a tradycyjnym polega na szczegółowym zdefiniowaniu rezultatów wszystkich planowanych wydatków i ich rozliczeniu. Budżet zadaniowy powinien być zrozumiały dla każdego mieszkańca, który może zobaczyć, na co gmina wydaje każdą złotówkę i jaki jest efekt tego wydatku. Pozwala to na lepsze zarządzanie finansami i porządkuje tzw. sferę kosztotwórczą [www2].

\section{Charakterystyka podmiotów badań}

W badaniach wzięło udział 45 gmin województwa warmińsko-mazurskiego. W próbie badawczej znalazło się 9 gmin miejskich, co stanowi 56\% wszystkich miejskich w województwie, 11 gmin miejsko-wiejskich, czyli 33\% danej grupy w województwie, oraz 25 gmin wiejskich, które stanowiły niecałe $40 \%$ w swojej grupie. Dobór próby był celowy i kierowany kryterium geograficznym. Ankietę przeprowadzono w gminach, które wyraziły chęć uczestnictwa w badaniu. 
Wśród badanych gmin blisko co piąta gmina zajmowała stosunkowo niewielką powierzchnię nieprzekraczającą $100 \mathrm{~km}^{2}$. Tyle samo badanych jednostek administracyjnych stanowiły gminy o powierzchni powyżej $300 \mathrm{~km}^{2}$. Pozostałe jednostki to gminy o powierzchni od 100 do $300 \mathrm{~km}^{2}$.

W próbie badawczej najliczniejszą grupę (ok. 40\%) stanowiły gminy o liczbie mieszkańców od 5000 do 10000 . Niecałe $20 \%$ to małe gminy od 2500 do 5000 mieszkańców. W co piątej gminie liczba mieszkańców wyniosła od 20000 do 40000. Tylko w 7\% gmin liczba mieszkańców przewyższała 40000.

\section{Wyniki badań}

Badania dotyczące budżetu zadaniowego w wybranych jednostkach samorządowych rozpoczęto od zweryfikowania liczby gmin, które posiadają budżet zadaniowy. Zgodnie z udzielonymi odpowiedziami tylko 4 gminy (9\%) opracowywały budżet $\mathrm{w}$ układzie zadaniowym ${ }^{1}$. Jest to niewielki odsetek jednostek, świadczący o tym, że gminy nie podejmują się tego zadania z uwagi na to, że nie jest to dla nich obligatoryjne. Przepis w ustawie o finansach publicznych z 2009 r. o ewidencji wykonywania budżetu w układzie zadaniowym ma bowiem dla samorządów charakter fakultatywny. Gminy często nie chcą dokładać sobie dodatkowych zajęć związanych z opracowaniem budżetu. Inną przyczyną wpływającą na brak budżetu zadaniowego może być fakt, iż jednostki samorządowe mają problem $\mathrm{z}$ jego opracowaniem i wdrożeniem. Przygotowanie budżetu w układzie zadaniowym, mimo wielu akcji szkoleniowych, nadal bywa skomplikowane i pracochłonne. Wymaga bowiem powiązania budżetu $\mathrm{z}$ wieloletnią prognozą finansową oraz opracowania mierników i wskaźników, dzięki którym można ocenić jego efektywność w przyszłości.

Brak działań mających na celu opracowanie budżetu zadaniowego może również wynikać z obawy przed innowacyjnością, z braku ambicji kadry zarządzającej gminą do usprawniania zarządzania finansami gminy, bądź też z braku dodatkowych środków finansowych na prace związane z opracowywaniem planu finansowego w nowej formie. Przyczyną może być także brak konieczności opracowania budżetu w układzie zadaniowym, szczególnie w małych gminach wiejskich, gdzie przejrzystość wydatkowania środków publicznych jest zachowana z uwagi na stosunkowo niskie wydatki.

Dysponując wiedzą na temat liczby gmin, które posiadają budżet zadaniowy, podjęto próbę zbadania, jakie kroki w kierunku tworzenia budżetu w układzie zadaniowym zostały dotychczas podjęte. Wyniki tego badania nie są zbyt optymistyczne, ponieważ aż w ponad połowie badanych gmin nie podjęto żadnych działań w kierunku opracowywania budżetu w układzie zadaniowym. Zaledwie w $18 \%$ badanych jednostek zostały przeprowadzone szkolenia na temat budżetu zadaniowego. Opis

${ }^{1}$ Spośród ponad 2,5 tys. gmin w Polsce prace nad budżetem zadaniowym - które są na różnym etapie realizacji - podjęło kilkadziesiąt polskich samorządów, m.in. gminy: Kraków, Poznań, Bielsko-Biała, Brzesko, Bychawka, Dukla, Gardeja, Gizałki, Gorzów [Chojna-Duch 2006, s. 254]. 
zadań z uwzględnieniem finansowania zrealizowano w 13\% ankietowanych gmin. Tylko w 9\% gmin utworzono bazę mierników i dokonano podziału zadań na podzadania. Były to jednocześnie gminy, które opracowywały już budżet z podziałem na zadania (rys. 1).

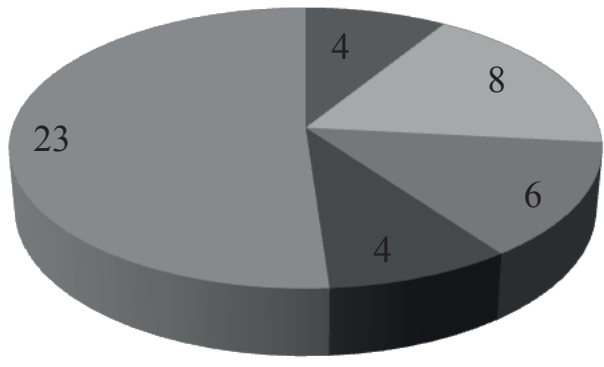

Tworzenie bazy
mierników
Szkolenia
Opis zadań
z uwzględnieniem ich
finansowania
Próba podziału zadań
na podzadania
Żadne

Rys. 1. Kroki podjęte w kierunku tworzenia budżetu zadaniowego

Źródło: opracowanie własne.

Ważnym krokiem w drodze do budżetu zadaniowego jest proces definiowania zadań i ustalenie mierników tych zadań, który jest jednocześnie najbardziej problematyczny dla jednostek opracowujących budżet zadaniowy po raz pierwszy. Najpierw powinno się odpowiednio przygotować szczegółowo zadania, a następnie określić cel tych zadań. Kolejnym krokiem powinno być ustalenie wskaźników wykonania zadań.

Chcąc poznać przyczynę tak małej liczby gmin, które posiadają budżet w układzie zadaniowym, a jednocześnie zapoznać się z doświadczeniami jednostek samorządowych, które etap wdrażania budżetu zadaniowego mają za sobą, zadano pytanie dotyczące trudności we wdrażaniu budżetu zadaniowego. Gminy wskazywały kilka trudności, na które natknęły się podczas swojej dotychczasowej pracy bądź też których się spodziewają z chwilą podjęcia się tego zadania (rys. 2).

Najczęściej wymienianą trudnością we wdrażaniu budżetu zadaniowego była długotrwałość i pracochłonność procesu tworzenia budżetu. Ten element wskazało aż 25 gmin (55\%) spośród 45-podmiotowej próby badawczej. Wprowadzenie w gminie budżetu zadaniowego jest procesem nie tylko długotrwałym, ale i złożonym, który nie przynosi natychmiastowych efektów w krótkim czasie. Wymaga zatem dużej cierpliwości.

Kolejnymi barierami we wdrażaniu planu finansowego w układzie zadaniowym, wskazywanymi przez niecałe 50\% ankietowanych gmin, były: wyliczanie kosztów 


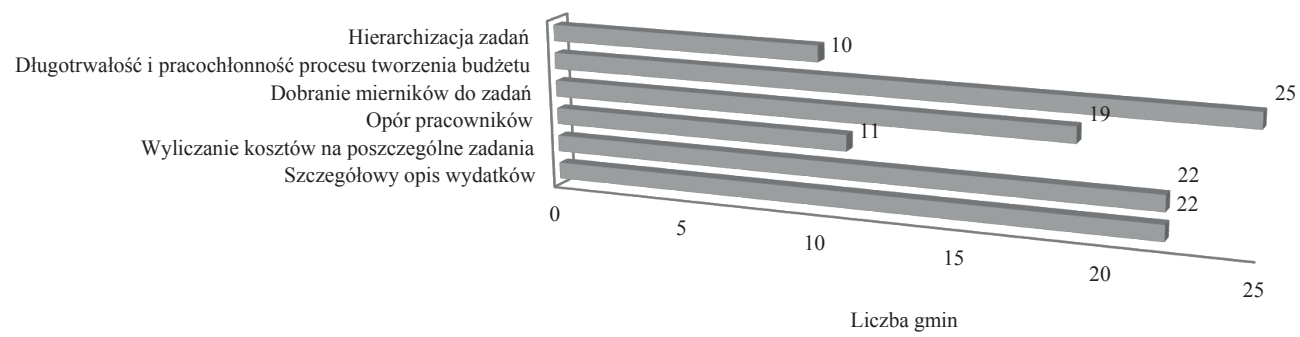

Rys. 2. Trudności we wdrażaniu budżetu zadaniowego

Źródło: opracowanie własne.

na poszczególne zadania oraz problem ze szczegółowym opisem wydatków. Zarówno pierwsze, jak i drugie utrudnienie wskazała co piąta badana jednostka.

$\mathrm{Z}$ kolei ponad $42 \%$ badanych gmin było przekonanych, że dużą przeszkodą we wdrażaniu budżetu zadaniowego jest konieczność dobrania odpowiednich mierników dla określonych zadań ${ }^{2}$. Trudność ta wiąże się z brakiem doświadczenia, wykwalifikowania i przygotowania kadry, która miałaby być za to odpowiedzialna.

W co czwartej badanej jednostce barierą w wdrażaniu budżetu w układzie zadaniowym była hierarchizacja zadań oraz opór pracowników związany ze wskazanymi wcześniej trudnościami. Pracownicy, nie posiadając doświadczenia i odpowiednich umiejętności, obawiają się, że nie poradzą sobie z nowym zadaniem. Ponadto niektórzy mogą być negatywnie nastawieni do konieczności poszerzania swojej wiedzy.

Należy pamiętać, że wdrażanie budżetowania zadaniowego to przedsięwzięcie, które przekracza swym zasięgiem granice problemów finansowych. Końcowym celem we wdrożeniu budżetu zadaniowego jest nie tylko zmiana kształtu dotychczasowego budżetu, lecz również zmiana myślenia o instytucjach publicznych, w tym samorządach gmin, oraz o ich funkcjonowaniu. Celem budżetu zadaniowego jest także zasadnicza zmiana w zarządzaniu owymi instytucjami. Wymaga to przede wszystkim zmian w sposobie myślenia nie tylko na szczeblu wójta, prezydenta czy burmistrza, ale całej administracji gminy.

Wdrożenie budżetowania zadaniowego nie jest zatem sprawą łatwą. Wymaga bowiem zmian nie tylko na poziomie technicznym, np. dostosowania systemu rachunkowości czy implementacji całego instrumentarium, służącego do oceny realizacji zadań wynikających z podjętych planów, ale również wprowadzenia odpowiednich zmian na wszystkich szczeblach struktur gminnych, co jest w dużej mierze uzależnione od umiejętności organizatorskich decydentów i potencjału kadrowego w danej gminie.

${ }^{2}$ Otrzymane wyniki potwierdziły wcześniej przeprowadzone badania wśród gmin, które wdrożyły budżet zadaniowy. Wynika z nich, że szczególnego wysiłku wymaga proces hierarchizacji zadań i definiowanie wskaźników efektywności [Owsiak (red.) 2002, s. 141]. 
Pomimo trudności we wdrażaniu budżetu zadaniowego istnieje wiele zalet i pozytywnych efektów, które są lub byłyby (w przypadku gmin, które nie przygotowały jeszcze budżetu w układzie zadaniowym) widoczne po wdrożeniu takiego planu finansowego (rys. 3). Wśród badanych gmin najczęściej wymienianą (62\%) zaletą budżetu zadaniowego jest jego przejrzystość zarówno dla pracowników, jak i dla mieszkańców ${ }^{3}$. Budżet zadaniowy ma bowiem jasno rozpisane zadania i podzadania, a także mierniki, które w konkretny sposób odzwierciedlają realizację postawionych zadań. Przejrzystość budżet zadaniowy zawdzięcza również temu, iż dokument ten jest bardzo pracochłonny, co za tym idzie - dokładny i zrozumiały nawet dla osób niezajmujących się zarządzaniem. Dzięki temu możliwe jest zwiększenie poziomu i intensywności opinii i debat społeczeństwa lokalnego dotyczących wydatkowania środków gminy.

Kolejnym pozytywnym efektem związanym z wdrożeniem budżetu zadaniowego była możliwość wieloletniego planowania wydatków oraz mobilizacja do osiągania lepszych wyników w zakresie wydatkowania funduszy. Odpowiedzi takie podało ponad $42 \%$ badanych jednostek. Budżetowanie zadaniowe zrywa $\mathrm{z}$ autokratycznym podejściem, występującym w budżetowaniu tradycyjnym, w którym plan finansowy jest narzucany podwładnym, wykonawcom przez ograniczone grono osób. Dzięki demokratyzacji tego procesu budowana jest odpowiedzialność pracowników gmin za wyznaczone cele, wydawane pieniądze publiczne i podejmowane działania (rys. 3).

Niewątpliwie możliwość wieloletniego planowania wydatków jest istotnym atutem, szczególnie w gospodarce, w której występują warunki złożoności oraz dynamika zjawisk i czynników mających współcześnie wpływ na finanse publiczne, w tym finanse gmin.

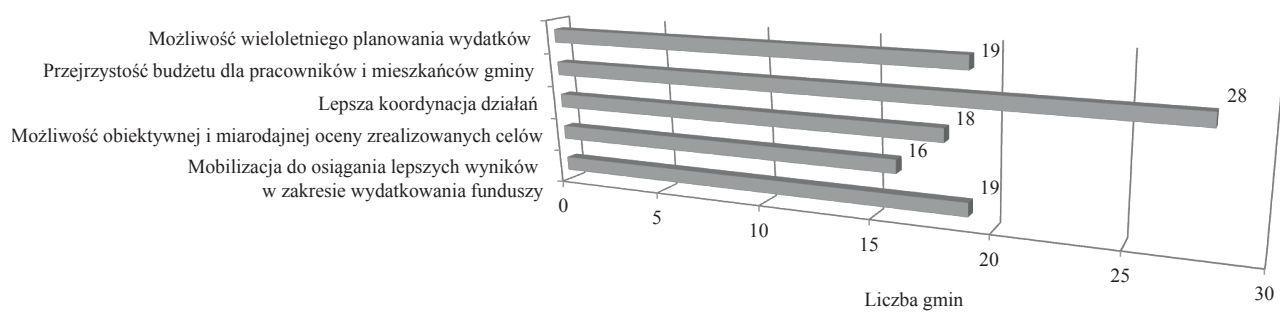

Rys. 3. Pozytywne efekty wdrożenia budżetu zadaniowego

Źródło: opracowanie własne.

Poza wcześniej wymienianymi pozytywnymi efektami $40 \%$ badanych gmin jako zaletę budżetu zadaniowego wskazało również lepszą koordynację działań. Ten efekt może wiązać się z lepszą identyfikacją zadań (rys. 3).

${ }^{3}$ Zaleta ta, wraz ze zwiększeniem odpowiedzialności podmiotów realizujących zadania, była również najczęściej wskazywana w badaniach nad budżetem zadaniowym przeprowadzonych w $2009 \mathrm{r}$. [Będzieszak 2009]. 
Kolejnym z pozytywnych efektów była możliwość obiektywnej oceny zrealizowanych celów. Taką zaletę zauważyło $35 \%$ gmin. Jak już wcześniej wspomniano, długotrwały proces, podczas którego zostają formułowane mierniki, przyczynia się do miarodajnego oceniania efektywności i skuteczności realizowanych zadań (rys. 3).

Wszystkie wymieniane przez badane gminy pozytywne efekty powinny motywować jednostki samorządowe do podejmowania działań zmierzających do wdrożenia budżetu zadaniowego. Należy jednak pamiętać, że proces tworzenia budżetu w układzie zadaniowym jest przedsięwzięciem pracochłonnym i wymagającym dużego zaangażowania wszystkich podmiotów, które są odpowiedzialne za jego realizację. Poza tym wdrażanie budżetu zadaniowego jest działaniem wieloletnim oraz złożonym, co powoduje, że nie przynosi w krótkim okresie natychmiastowych efektów.

\section{Zakończenie}

Koncepcja budżetu zadaniowego jest znacznym udoskonaleniem klasycznego budżetowania w gminie. Polskie gminy dostrzegają wiele korzyści, które można uzyskać dzięki wdrożeniu budżetu zdaniowego. Jednakże trudności, których spodziewają się podczas jego wdrażania, okazują się silniejsze, ponieważ jak dotąd liczba gmin, które opracowują budżet $\mathrm{w}$ układzie zadaniowym, jest niewielka (jedynie 4 spośród 45 badanych gmin). Co więcej, ponad połowa badanych gmin nie podjęła dotychczas żadnych kroków w kierunku wdrażania budżetu zadaniowego. Największe obawy dotyczące wdrażania budżetu zadaniowego budziły długotrwałość i pracochłonność tego procesu oraz dobranie odpowiednich mierników.

Zgodnie $\mathrm{z}$ prawem finansów publicznych budżet zadaniowy nie zastępuje budżetu tradycyjnego, a jedynie stanowi dodatkową formę zapisów. W efekcie takiego niedostosowania przepisów gminy, które wprowadzają budżet zdaniowy, nie mogą zrezygnować z budżetu tradycyjnego, co powoduje, że niechęć do tworzenia nowego planu finansowego wzrasta. Zmiana w przepisach prawnych powodująca, że budżet zadaniowy nie tyle stałby się obowiązkowym narzędziem w zarządzaniu gminami, co mógłby być stosowany bez konieczności jednoczesnego tworzenia budżetu tradycyjnego, mogłaby doprowadzić do zwiększenia liczby jednostek samorządowych, które rozpoczęły proces tworzenia budżetu w układzie zadaniowym.

Wprowadzenie budżetu zadaniowego w gminach wymaga odpowiednich środków finansowych, przygotowania merytorycznego pracowników, określonego sformalizowania procesów budżetowania. Największą trudnością dla badanych gmin jest pracochłonność i długotrwałość procesu tworzenia budżetu w układzie zadaniowym, natomiast największym oczekiwaniem po wdrożeniu budżetu zadaniowego jest chęć stworzenia planu finansowego, który będzie bardziej przejrzysty. Poza tym jednostki samorządowego oczekują poprawy procesu zarządzania w gminie.

Budżet zadaniowy należy postrzegać jako narzędzie racjonalizacji gospodarki finansowej i poprawy efektywności gospodarowania. Ma on zatem uzasadnienie głównie w dużych gminach, gdzie zakres i struktura zadań publicznych jest odpowiednio 
większa i jego konstrukcja jest bardziej złożona. Natomiast w mniejszych gminach, gdzie skala środków jest mała, nie ma potrzeby ponosić tak dużego wysiłku koncepcyjnego, organizacyjnego i finansowego.

\section{Literatura}

BAS, 2013, Budżet zadaniowy, Studia Biura Analiz Sejmowych, nr 1(13).

Będzieszak M., 2009, Model budżetu zadaniowego samorząów w świetle badań, Zeszyty Naukowe US, nr 547 - Ekonomiczne Problemy Usług, nr 37: Finanse 2009 - teoria i praktyka. Finanse publiczne II, red. B. Filipiak, B. Walczak, Wydawnictwo Naukowe Uniwersytetu Szczecińskiego, Szczecin.

Chojna-Duch E., 2006, Polskie prawo finansowe. Finanse publiczne, Wydawnictwo Prawnicze LexisNexis, Warszawa.

Dylewski M., 2007, Planowanie budżetowe w podsektorze samorządowym. Uwarunkowania, procedury, modele, Difin, Warszawa.

Filas J., Piszczek M., Stobnicka M., 1999, Budżet zadaniowy - narzędzia i procedury, Agencja Rozwoju Komunalnego, Warszawa.

Franek S., 2015, Budżet zadaniowy w jednostkach samorzadu terytorialnego - specyfika stosowanych rozwiazań, Prace Naukowe Uniwersytetu Ekonomicznego we Wrocławiu, nr 404, Finanse samorzadu terytorialnego, s. 118.

Lubińska T. (red.), 2011, Kierunki modernizacji zarządzania w jednostkach samorzadu terytorialnego, Difin, Warszawa.

Malinowska-Misiąg E., Misiąg J., Misiąg W., Tomalak M., 2015, Metody budżetowania zadaniowego w jednostkach samorzadu terytorialnego. Przewodnik, Presscom, Warszawa.

Owsiak S. (red.), 2002, Budżet władz lokalnych, PWE, Warszawa.

Pakoński K., 2000, Zintegrowane zarządzanie finansami zorientowane na cele, Municipium, Warszawa. Ustawa z dnia 27 sierpnia 2009 r. o finansach publicznych, Dz.U. z 2009, nr 157, poz. 1240 z późn. zm. [www1] http://www.budzet-zadaniowy.com/budzet_zadaniowy_w_samorzadach/index.html (6.03.2017).

[www2] http://www.rp.pl/artykul/716743-Budzet-zadaniowy-w-gminach.html\#ap-1 (14.09.2011). 